\title{
PENDIDIKAN ORANG DEWASA SEBAGAI BASIS PENDIDIKAN NON FORMAL

\section{Abstrak}

Dalam sistim pendidikan nasional, pendidikan non formal dianggap setara degan pendidikan formal. Kedua jenis pendidikan ini hanya berbeda dalam soal konteks, waktu, tujuan, dan karakter peserta didiknya. Pendidikan orang dewasa merupakan salah satu pendekatan dalam pelaksanaan pendidikan non formal karena sebagian besar peserta didiknya orang dewasa, yang datang dengan berbagai latar belakang sosial budaya, pengalaman, minat, dan tujuan yang berbeda. Rendahnya hasil belajar sebagai indikator dari ketidakberhasilan pembelajaran, dimana peserta tidak mampu menerima dengan baik bahan belajar yang diajarkan oleh tutor merupakan masalah dalam pendidikan no formal. Salah satu penyebabnya adalah prinsip dan teori pendidikan orang dewasa (andragogi) belum diterapkan secara maksimal dalam pelaksanaan pembelajaran

Pendidikan orang dewasa dapat memecahkan berbagai persoalan kehidupan sehar-hari, termasuk berbagai musibah yang beruntun menimpa masyarakat Indonesia. Dengan pendekatan pendidikan orang dewasa melalui beberapa strategi dan teori belajar yang dikembangkan menurut falsafah kerja yang tepat, pemulihan mental dan aspek fisik lainnya dapat segera dilakukan. Demikian juga berbagai persiapan pendidikan bagi orang dewasa ke depan juga dapat dirancang melalui pemahaman falsafah kerja orang dewasa.

*) Ir. Tasril Bartin, M.Pd., adalah Tenaga Fungsional Pendidikan Non Formal pada Pemkab Tanah Datar Provinsi Sumatera Barat 
Kata Kunci: orang dewasa, pendidikan non formal, minat, kebutuhan, dan falsafah kerja.

\section{A. PENDAHULUAN}

Perumusan Sistim Pendidikan Nasional sebagaimana yang diatur dalam Undang-undang nomor 20 tahun 2003 sebenarnya mengacu kepada empat pilar pendidikan yang ditetapkan oleh Unesco (1999), yaitu pendidikan adalah belajar untuk tahu (learning to know), belajar untuk berbuat (learning to do), belajar untuk menjadi diri sendiri (learning to be), dan belajar untuk bermasyarakat (learning to live together). Khusus, pelaksanaan pendidikan luar sekolah, menurut Sihombing (2000), keempat pilar tersebut perlu ditambah dengan belajar untuk membangkitkan kembali apa yang pernah kita miliki namun terlupakan (learning to recapture) dan belajar untuk membuang kebiasaan yang tak berguna yang pernah kita miliki (learning to unlearn)

Pendidikan Non Formal sebagaimana terdapat dalam UU nomor 20 tahun 2003 tersebut meliputi pendidikan kecakapan hidup, pendidikan anak usia dini, pendidikan kepemudaan, pendidikan pemberdayaan perempuan, pendidikan keaksaraan, pendidikan keterampilan dan pelatihan kerja, pendidikan kesetaraan, serta pendidikan lain untuk mengembangkan kemampuan peserta didik.

Kesadaran masyarakat tentang pentingnya pendidikan non formal akhir-akhir ini tumbuh pesat. Hal ini tecermin dari tumbuh dan berkembangnya berbagai lembaga kursus dan pusat-pusat pendidikan lainnya yang dikembangkan oleh masyarakat. Lebihlebih pendidikan kecakapan hidup yang telah menjadi primadona program pendidikan non formal terutama yang dibina oleh Direktorat Jenderal Pendidikan Luar Sekolah dianggap berperan besar dalam upaya pengentasan kemiskinan dan pengangguran yang selalu masalah utama di negeri ini.

Peserta pendidikan non formal sebagian besar adalah orang dewasa, dimana sesuai dengan sifatnya sebagai orang dewasa ia 
dating dan mencari pendidikan kepada lembaga dan siapapun atas dorongan kebutuhan untuk memperbaiki kualitas diri terutama kebutuhan akan kompetensi tertentu yang dapat membantu mereka meringankan persoalan hidup sehari-hari. Dengan demikian, krisis ekonomi dan perubahan social yang sangat cepat merupakan salah satu alasan setiap orang dewasa berpikir untuk selalu belajar (long life education).

Begitu beratnya tantangan hidup sebagaimana disebutkan di atas, membuat masyarakat sekarang cenderung untuk berpikir pragmatis dan instant, termasuk kecenderungan mereka untuk memiliki jenis pendidikan tertentu. Karena itu mereka hanya mencari pendidikan yang murah dan menjamin untuk bisa bekerja di lingkungan perusahaan atau bekerja mandiri.

Berdasarkan Undang-Undang di atas dan fenomena yang terjadi di masyarakat, dapat ditarik benang merahnya bahwa pendidikan formal dan pendidikan non formal adalah ibarat dua sisi mata uang yang komplementer. Kedua jalur pendidikan tersebut sama pentingnya namun berbeda dalam konteksnya (waktu, tempat, tujuan, dan jenis peserta didik). Karena itu diharapkan tidak ada lagi pihak yang memandang sebelah mata tentang pentingnya pendidikan non formal, terutama bagi mereka yang memegang otritas pendidikan di negeri ini. Artinya kondisi di atas perlu diantisipasi secara lebih serius dan mendalam. Paradigma Pendidikan Non Formal yang dulunya cenderung sentralistis dan bernuansa kuat dengan warna kekuasaan dan bersifat seragam harus segera diubah menjadi paradigma baru, yang lebih berorientasi pada pemberdayaan masyarakat termasuk pemberdayaan masyarakat daerah, atau bersifat desentralisasi dengan membuka seluas-luasnya kesempatan akan pemenuhan keanekaragaman kebutuhan masyarakat.

Permasalahan yang paling sering muncul dalam pelaksanaan pendidikan non formal adalah hasil belajar, output dan outcomenya tidak sesuai dengan yang diharapkan. Ketidakmampuan peserta 
memahami dengan baik materi dalam bentuk pengetahuan, sikap, dan keterampilan merupakan indikasi kurang berhasilnya kegiatan pendidikan non formal. Rendahnya hasil belajar sebagai indikator dari ketidakberhasilan pembelajaran, dimana peserta tidak mampu menerima dengan baik bahan belajar yang diajarkan oleh tutor. Salah satu penyebabnya adalah prinsip dan teori pendidikan orang dewasa (andragogi) belum diterapkan secara maksimal dalam pelaksanaan pembelajaran.

Secara jelas Knowles (1979) menyatakan apabila peserta didik (baca: warga belajar) telah berumur 17 tahun, penerapan prinsip belajar orang dewasa dalam kegiatan pembelajarannya telah menjadi suatu kelayakan. Usia warga belajar pada kelompok belajar program non formal rata-rata di atas 17 tahun, sehingga dengan sendirinya penerapan prinsip pembelajaran orang dewasa pada kegiatan pembelajarannya semestinya diterapkan.

\section{B. PERKEMBANGAN PENDIDIKAN ORANG DEWASA}

Di waktu lampau, pendidikan orang dewasa pada umumnya hanya sebagai pelengkap dalam kekurangan pendidikan formal saja, atau membantu mereka yang tidak sempat mengikuti pendidikan formal di persekolahan. Sifatnya hanya digunakan tatkala diperlukan saja, namun kecenderungan sekarang berubah kearah kelompok diskusi yang terlaksana dalam satuan pendidikan non formal seperti kelompok belajar dengan tema memecahkan masalah pekerjaan, individu, keluarga, daerah, nasional, dan internasional. Diskusi kelompok ini semakin meluas kurikulumnya dan makin besar jumlah pesertanya dan tanpa mereka sadari merupakan suatu bentuk kegiatan pendidikan non formal yang banyak digandungi oleh orang dewasa (misalnya dalam bentuk seminar, lokakarya, diklat, kursus, dan sebagainya).

Pendidikan orang dewasa juga merupakan salah satu nuansa pendidikan yang sering diterapkan untuk meningkatkan kinerja pegawai atau buruh di suatu industri. Demikian juga berbagai 
lembaga pemerintah dan swasta yang secara sadar maupun tidak telah menjalankan usaha pendidikan bagi para karyawan dan anggotanya.

Pendidikan orang dewasa lahir sebagai kejenuhan dalam pelaksanan pola pendidikan formal yang berlaku dan tidak sesuai dengan sifat dan karakter orang dewasa, yaitu mengganti kuis dengan wawancara, tanya jawab, dan diskusi-diskusi. Ternyata pola pendidikan ini disenangi peserta didik.

Secara ilmiah pendidikan orang dewasa diakui keberadaannya setelah Houle pada tahun 1961 melakukan pengamatan dan wawancara mendalam terhadap beberapa orang, dimana ditemukan 3 kelompok orientasi, yaitu : 1) goal oriented group (kelompok yang berorientasi pada tujuan), yang beranggapan pendidikan sebagai sarana mencapai tujuan, 2) activity oriented group ( kelompok berorientasi pada kegiatan), yaitu kelompok yang menemukan manfaat dari situasi belajar, 3) learning oriented group (kelompok yang berorientasi pada ilmu itu sendiri) yaitu untuk pengembangan Imu itu sendiri.

\section{HAKEKAT PEMBELAJARAN ORANG DEWASA - Konsep Pendidikan Orang Dewasa}

Di luar negeri kegiatan pendidikan orang dewasa ini mempunyai berbagai macam istilah. Misalnya Unesco menggunakan istilah fundamental education, yang juga dipergunakan di Spanyol. Di Perancis dikenal dengan basic education, sedangkan India menggunakan istilah social education. Di Amerika Serikat dan Canada dikenal dengan istilah adult education, dan bekas jajahan Inggris menggunakan istilah mass education, dan Indonesia dan Filipina menggunakan istilah community education.

Menurut Boyd (1966), pendidikan orang dewasa dapat didefenisikan sebagai suatu seni dalam membantu orang 
dewasa belajar melalui suatu proses pendidikan pada diri seseorang yang dilaksanakan secara non formal pada orang yang dianggap dewasa, dimana isi pelajaran ditentukan sendiri oleh orang dewasa tersebut.

Sementara dalam pengertian yang lebih luas pendidikan orang dewasa dapat diartikan sebagai satuan pendidikan yang cenderung non formal dengan peserta didiknya adalah orang dewasa (dewasa dalam pengertian biologis, psikologis, ekonomi, hukum, dan sosial), yang dilaksanakan sedemikian rupa yang bertujuan untuk membantu orang dewasa tersebut belajar dalam rangka menciptakan dan mengembangkan minat baru, pengembangan pengetahuan, peningkatan keterampilan, dan perbaikan sikap mental sesuai dengan keadaan lingkungan sosial, ekonomi, dan budaya orang dewasa tersebut, dan pada akhirnya dapat membantu orang dewasa tersebut memenuhi kebutuhannya.

Pendekatannya mengikuti sifat orang dewasa itu sendiri, dimana orang dewasa sebelum mengikuti pendidikannya ia sudah memiliki suatu pengetahuan, kemampuan umum dan khusus, kepentingan, sikap, praduga, kebiasaan, nilai, dan tingkat emosi sebagai orang dewasa. la juga memiliki beberapa tanggung jawab seperti di tempat kerja, di rumah, dan di masyarakat. la juga punya waktu, tenaga, pikiran, dan uang yang terbatas. Artinya tingkat dan kualitas belajar di kalangan orang dewasa terdapat perbedaan yang sifatnya perorangan. Karena itu pendekatan yang digunakan lebih bersifat fungsional, pragmatis, dan aplikatif sesuai dengan situasi dan kondisi lingkungan ekonomi, sosial dan budayanya. Sehubungan dengan itu Dharm Vir (1993) mengatakan pengingatan dan praktek yang segera merupakan suatu keharusan dalam pendidikan orang dewasa, karena pelajar dewasa cenderung lupa akan pelajaran yang sudah diterimanya. 


\section{- Tujuan Pendidikan Orang Dewasa}

Tujuan utama orang dewasa belajar adalah dalam rangka memenuhi kebutuhan hidupnya, maka (Boyd, 1966) mengatakan bahwa sebagai persyaratan dasar orang dewasa belajar adalah atas maksud ingin tahu berdasarkan kebutuhan tadi. Dengan demikian pendapat Boyd tersebut dapat diartikan bahwa materi pembelajaran orang dewasa tersebut harus menyangkut persoalan hidup sehari-hari. Topiknya bisa halhal yang berkaitan dengan: 1) perbaikan kualitas hidup, 2) keingintahuan akan sesuatu hal yang menarik perhatian atau berkaitan dengan bakat dan minat, 3) peningkatan kompetensi tentang sesuatu hal, dan 4) sebagai kebutuhan akan gelar atau prestise. Yang penting, secara fsikologis pendidikan tersebut dapat memberikan kepuasan atau kebahagian kepada pribadi yang bersangkutan.

Houle (1961) menekankan tujuan pendidikan orang dewasa adalah pada penyesuaian minat dan kebutuhan serta membangun kepemimpinan secara informalitas. Sementara Bergenvin menekankan pada upaya membantu orang dewasa meraih suatu derajat kebahagiaan dan arti kehidupan. Dengan pendidikan orang dewasa, setiap orang dapat memahami diri sendiri, mengenali kelebihan dan kekurangannya, serta lebih matang secara spritual, sosial, budaya, fisik, dan beragai kecakapan hidup.

Perlunya penerapan prinsip pembelajaran orang dewasa (andragogi) dalam pendekatan pendidikan non formal disebabkan pendidikan non formal umumnya diikuti oleh pelajar dewasa, dimana upaya membelajarkan orang dewasa berbeda dengan upaya membelajarkan anak. Membelajarkan anak (pedagogi) lebih banyak merupakan upaya mentransmisikan sejumlah pengalaman dan keterampilan dalam rangka mempersiapkan anak untuk menghadapi kehidupan di masa datang. Apa yang di transmisikan didasarkan pada 
pertimbangan apakah hal tersebut akan bermanfaat bagi warga belajar di masa datang. Sebaliknya, pembelajaran orang dewasa (andragogi) lebih menekankan pada membimbing dan membantu orang dewasa untuk menemukan pengetahuan, keterampilan, dan sikap dalam rangka memecahkan, masalahmasalah kehidupan yang dihadapinya. Ketepatan pendekatan yang digunakan dalam penyelenggaraan suatu kegiatan pembelajaran tentu akan mempengaruhi hasil belajar warga belajar.

Perbedaan antara membelajarkan anak-anak dengan membelajarkan orang dewasa terlihat dari upaya pembelajaran orang dewasa. Membelajarkan orang dewasa bersifat humanistic yaitu berpusat pada warga belajar itu sendiri (learned centered). Tutor harus memperhatikan prinsip-prinsip belajar orang dewasa. Prinsip tersebut dijadikan pegangan atau panduan dalam praktek membimbing kegiatan belajar orang dewasa. Pendekatan-pendekatan pembelajaran orang dewasa dengan memperhatikan prinsip-prinsip belajarnya dapat dipandang sebagai ilmu dan seni (art and science) membantu atau menolong orang dewasa belajar.

- Model Pembelajaran Orang Dewasa

Model pembelajaran orang dewasa sangat bervarisi tergantung situasi yang dihadapi dan pada lapisan apa orang dewasa tersebut berada. Model yang terbaik menurut Mead (dalam Boyd, 1966) adalah bersifat lateral transmition, partispatif, dan dialogis. Hal ini dapat diartikan bahwa sharing ilmu pengetahuan secara tidak formal dapat dikembangkan secara terus menerus tanpa memperhatikan umur dan latar belakang sosial seseorang.

Dalam pendidikan orang dewasa tidak ada istilahnya peserta didik yang pintar dan yang bodoh, yang ada hanya perbedaan kecepatan yang berkaitan dengan waktu dan kesempatan seseorang dalam memperoleh informasi atau pengetahuan. 
Dalam hal tertentu, seseorang dewasa yang lebih muda bisa saja mempunyai ilmu pengetahuan yang lebih banyak dari yang lainnya. Karena itu peranan pendidik orang dewasa adalah mendorong peserta didik (orang dewasa) dalam meningkatkan usahanya menciptakan iklim belajar yang sesuai dengan yang diinginkan.

Sehubungan dengan itu, agar proses pembelajaran menjadi lebih efektif dan efesien, (Dharm Vir, 1993) mengatakan bahwa secara operasional pendidik bersama peserta didik harus mengidentifikasikan tujuan pendidikan dan berdasarkan tujuan tersebut disusun rencana pendidikan, dimana pendidikan tersebut harus merupakan suatu kesenangan, tantangan yang berguna, dan usaha yang hasilnya penuh manfaat.

Disebabkan rumitnya persoalan yang dihadapi orang dewasa dan berbeda-beda pada setiap orang maka sebagai pendidik orang dewasa kita perlu memahami landasan untuk memahami persoalan-persoalan pendidikkan tersebut dan hubungannya dengan lingkungan masyarakat. Pendekatan yang tepat akan membantu menjawab setiap pertanyaan yang muncul. Dengan demikian pembangunan falsafah kerja pendidikan orang dewasa perlu dikembangkan secara baik untuk membantu dalam pemaknaan tentang kehidupan orang dewasa. Filsafah kerja tersebut meliputi pelajar itu sendiri, tujuan pendidikan, isi atau materi, serta proses pembelaaran.

\section{IMPLEMENTASI POD DALAM MEMBANTU PEMULIHAN MASYARAKAT DARI DAMPAK BENCANA ALAM}

- Penyadaran Fisikologis hakekat hubungan manusia dan alam

Menurut Apps (1973) manusia pada tingkatan tertentu adalah bagian dari lingkungan alam, karena itu manusia sangat 
tergantung kepada alam dan dikendalikan oleh alam. Bencana bisa saja mengancam keselamatan manusia sepanjang waktu. Setiap individu atau kelompok tidak bisa mengelakan dan meramalkan kapan datangnya, kecuali hanya bisa meminimalisir dampak dari musibah tersebut.

Sehubungan dengan itu teori kepercayaan tentang pelajar dewasa dapat diarahkan untuk memunculkan kesadaran fisikologis kepada masyarakat bahwa dimanapun kita tinggal bencana alam dapat saja terjadi, semua itu adalah takdir dan kodrat alam. Dengan demikian sebagai perancang pendidikan orang dewasa kita dapat menata situasi pendidikan orang dewasa sesuai dengan kondisi lingkungan alamnya tadi. Sebagai contoh, untuk mengurangi resiko tsunami, masyarakat di sekitar pesisir perlu diajari bagaimana mengenali tanda-tanda tsunami melalui simulasi-simulasi, atau masyarakat yang tinggal di kaki bukit dapat pula diajari bagaimana memilih dan membuat pemukiman yang aman dari bahaya longsor.

Jadi dengan mempelajari kondisi alam di sekitarnya manusia menjadi sadar dan dapat membuat suatu skenario program penyelamatan untuk meminimalisir efek/ resiko bila bencana terjadi yaitu dengan menyiapkan diri secara mental dan rencana tindakan bila musibah itu terjadi lagi, dan pada gilirannya masyarakat menjadi tenang kembali dalam bekerja tanpa dihantui terus menerus bencana alam yang tidak pernah terduga sama sekali. Sebagai contoh : musibah gempa dan tsunami paling sering terjadi di Jepang, tapi pemerintahnya telah mendidik dan menyadarkan masyarakatnya untuk mempersiapkan diri dengan program-program penyelamatan guna mengurangi efek/resiko bencana tersebut. Dengan demikian, masyarakatnya menjadi sadar bahwa memang ia hidup di suatu negeri yang penuh resiko bencana gempa dan tsunami, karena itu yang paling penting adalah persiapan untuk menghadapi bencana tersebut. Setelah bencana itu terjadi 
mereka akan cepat memulihkan diri seperti sedia kala, baik secara psikologis maupun secara materil.

\section{- Penentuan tujuan, kontent, dan proses belajar}

Setelah terjadinya berbagai musibah/ bencana yang menimpa sekelompok masyarakat, maka untuk memulihkan kondisi alam dan fisikologis masyarakat diperlukan pemahaman terhadap kebutuhan masyarakat tersebut. Jangan sampai kita salah dalam menyusun daftar kebutuhan belajar yang tepat karena dapat menambah ruwet persoalan dan menambah derita batin masyarakat yang terkena musibah. Disinilah letak pentingnya pendidikan orang dewasa tersebut, dimana bentuk, proses, dan pendekatan pendidikan orang dewasa sangat fleksibel dan situasional tergantung pada situasi yang terjadi saat itu.

Pendidikan orang dewasa selalu berorientasi pada minat dan tujuan, dengan demikian kita dapat mendiagnosa apa kebutuhan materil dan fsikologis yang segera diperlukan setelah musibah terjadi. Hanya dengan memahami pendidikan orang dewasa kita tahu bahwa keterlibatan orang dewasa/ masyarakat dalam proses belajar jauh lebih besar, sebab diagnosa kebutuhan, merumusan tujuan, dan mengevaluasi hasil belajar serta mengimplemen-tasikanya dilakukan secara bersama-sama. Dengan demikian, berdasarkan pemahaman tadi kita bisa menyusun suatu proyek belajar berdasarkan kebutuhan, tujuan, konten, dan proses belajar yang paling sesuai sehingga dapat membantu memulihkan kondisi sosial dan alam seperti sedia kala.

\section{- Membantu Masyarakat Belajar untuk Membentuk Prilaku Baru}

Dengan terjadinya bencana alam yang beruntun pada beberapa wilayah Indonesia, maka masyarakat di daerah bersangkutan mulai menyadari bahwa musibah ini terjadi juga disebabkan campur tangan manusia. Pengalaman bencana yang dialami dapat memotivasi secara internal untuk merubah kebiasaan 
buruk yang tidak besahabat dengan alam. Akan muncul prilaku baru bagaimana menghindari agar masalah tersebut tidak terulang lagi di masa datang. Akan timbul kesadaran untuk tidak lagi merusak alam, seperti melakukan penebangan liar, pembakaran hutan, membuang sampah ke sungai, dan lain sebagainya. Benar apa yang dikatakan Skinner (1954) bahwa prinsip belajar shaping dan extinction dengan teknik reinforcement dapat membentuk prilaku baru manusia dan hewan. Artinya bencana sebagai reinforcement dapat menyadarkan manusia untuk tidak membuat lagi kesalahannya di masa lalu dan berusaha mencari upaya tertentu agar dapat hidup tenang tanpa dihantui musibah/ bencana terus menerus. Dengan pendekatan pendidikan orang dewasa kita dapat dengan mudah menyadarkan mereka dari kekurangannya selama ini kemudian membimbing dan mendidik mereka untuk memunculkan prilaku baru seperti membuat rumah yang lebih kuat dengan bangunan tahan gempa, tidak membangun rumah di pinggir jurang, meningkatkan rasa gotong royong untuk menanggulangi bencana sehingga banyak program yang dapat dilakukan untuk memulihkan keadaan agar masyarakat dapat hidup tenang kembali seperti sedia kala.

\section{E. PERKEMBANGAN PENDIDIKAN ORANG DEWASA INDONESIA DI MASA DEPAN}

Berbicara soal pendidikan orang dewasa tentunya diskusi kita lebih banyak membicarakan permasalahan pendidikan dalam konteks pendidikan non formal. Dasar pelaksanaan pendidikan non formal ini telah ditegaskan dalam Undang-Undang Nomor 20 tahun 2003 tentang Sistim Pendidikan Nasional. Undang-undang tersebut menyebutkan bahwa pendidikan di Indonesia terbagai atas Pendidikan Formal, Pendidikan Non Formal, dan Pendidikan Informal. Berbeda dengan Undang-undang sebelumnya yaitu Undang-Undang Nomor 2 tahun 1989, yang menyatakan bahwa pendidikan terdiri dari Pendidikan Formal dan Pendidikan Luar Sekolah. 
Munculnya berbagai polemik seputar persoalan pendidikan di Indonesia yang berujung pada perubahan undang-undang pendidikan tersebut, kita dapat menarik suatu benang merah bahwa pendidikan di Indonesia perlu ditata sesuai dengan kebutuhan zaman. Setelah terjadinya kegagalan pendidikan di sektor pendidikan formal, pemerintah mulai menyadari bahwa pendidikan non formal juga perlu digenjot dan mendapat porsi yang lebih dari biasanya walaupun porsinya tidak persis sama dengan porsi yang diberikan pada pendidikan formal, tapi yang penting ada peningkatan perhatian dari tahun ke tahun.

Kesalahan bangsa selama ini dalam pengelolaan pendidikan adalah karena kita terlalu memisahkan pelaksanaan pendidikan formal dengan non formal maupun informal. Padahal ketiga aspek pendidikan tersebut perlu dilaksanaka secara sinergis, simultan dan komplementer. Akhir dari proses pendidikan tersebutlah yang menentukan bagaimana orang tersebut dapat menggunakan ilmunya yang diperoleh selama mengikuti proses pendidikan agar bisa digunakan dalam mengatasi persoalan hidup. Karena itu penyeragaman pelaksanaan pendididkan, baik formal maupun non formal dari Sabang sampai Merauke yang bernuansa indoktrinasi dan menyeramkan bagi peserta didik perlu segera ditinggalkan, Apalagi pendidikan orang dewasa bersiat andragogis, model pendidikannya harus fleksibel karena diikuti oleh peserta didik yang sudah matang secara fisiologis dan sosiolosis dan datang dengan berbagai persoalan hidup dan latar belakang sosial- budaya yang berbeda.

Percepatan pelaksanaan pendidikan non formal sebagaimana yang banyak dibicarakan di atas merupakan suatu momentum yang tepat seiring dengan terjadinya berbagai krisis yang berkepanjangan di semua lapisan kehidupan bangsa ini. Hal pokok yang mendasari perlunya pendidikan non formal adalah tujuan dan muatan dari pendidikan non formal tersebut. Pendidikan non formal sebenarnya merupakan satuan pendidikan yang dilaksanakan dengan tujuan 
untuk meningkatkan kecakapan hidup (life skills) bagi peserta didiknya, dimana kecakapan hidup ini merupakan syarat utama agar seseorang yang menyandang prediket dewasa untuk dapat eksis dalam hidupnya. Karena itu, kedepan persoalan pendidikan orang dewasa hendaknya perlu mendapat perhatian lebih dari pembuat kebijakan.

Sehubungandengan itu falsafah pendidikan yang dibangun adalah pendidikan yang melahirkan kewirausahaan dan kemandirian baik dalam memilih jenis pendidikan dan mengikuti proses pembelajaran itu sendiri. Keterbelakangan masyarakat dan ketertinggalan suatu kawasan dapat diatasi dengan memotivasi masyarakatnya untuk mengenali potensi diri dan lingkungannya. Masyarakat perlu dilatih mengidentifikasi persoalan hidup sendiri dan dibimbing mencari pemecahannya. Mereka perlu diajak untuk belajar mencari bebagai alternatif dalam mengatasi persoalan hidup. Pola dan pendekatan pendidikan orang dewasa perlu dilaksanakan, dimana orang dewasa tidak mau digurui, dipaksa, dan perlu dihargai sebagai manusia. Suasana pendidikan dengan pelajar dewasa, baik dalam lingkup pendidikan formal maupun non formal hendaklah lebih berpusat pada siswa (student center leanrning), Karena itu program-program pendidikan melalui generalisasi dan penyeragaman program yang asal ditiru dari daerah lain dan tidak mengacu kepada karakteristik lokal perlu segera ditinggalkan. Polapola pencerahan dan peningkatan kehidupan masyarakat di sana hendaklah dengan "memberikan kail, bukan ikan". Sesuai dengan tujuan pendidikan orang dewasa, dalam jangka pendek dan urgen, masyarakat disana perlu mendapatkan pendidikan yang sesuai dengan kebutuhannya untuk segera mengatasi persoalan hidupnya.

Sehubungan dengan uraian di atas lalu timbul pertanyaan, bagaimana model pendidikan orang dewasa yang perlu dirancang untuk perkembangannya di masa depan di negara Indonesia ini? Untuk menjawab pertanyaan ini penulis menawarkan beberapa strategi pendidikan orang dewasa di masa depan, diantaranya : 
- Kampanye Pendidikan Sepanjang Hayat (Long life education)

Sesuai dengan sifatnya sebagai orang dewasa yang memikul berbagai tanggung jawab baik di keluarga maupun dimasyarakat, maka orang dewasa tersebut tidak boleh berhenti belajar karena persoalan hidup akan selalu datang silih berganti sepanjang hayatnya. Perlunya pendidikan sepanjang hayat ini tidak terlepas dari ketergantunga manusia pada alam dan lingkungan sosialnya, dimana alam akan melahirkan perubahan teknologi dan perubahan teknologi juga menghasilkan perubahan sosial yang luar biasa. Karena itu belajar sepanjang hidup adalah suatu kebutuhan bagi manusia dewasa. Pada gilirannya akan dicapai terwujudnya individu dan masyarakat yang cerdas, terampil, mandiri, berdaya saing, dan gemar membaca.

- Memperbanyak Akses ke Pendidikan Non Formal Kebutuhan belajar ini akan terus berubah seiring dengan perubahan zaman, dimana setiap orang perlu membekali dirinya dengan berbagai keterampilan atau kecakapan dalam berbagai hal agar mereka tetap bisa survive. Kondisi ini kadangkadang tidak memungkinkan orang tersebut kembali ke ruang kelas untuk mengikuti pendidikan formal. Karena itu untuk mendapatkan kompetensi yang terkait dan relevan dengan kebutuhan individu, kebutuhan dunia kerja, dan pengembangan sumberdaya alam maka orang dewasa tersebut perlu memperbanyak memasuki ruang-ruang pendidikan non formal, baik yang dilaksanakan oleh pemerintah maupun swasta, seperti dalam bentuk penyuluhan, kursus, latihan, dan lain sebagainya.

- Reorientasi Pendidikan Menuju Kecerdasan Perilaku

Artinya pendidikan pada orang dewasa tidak hanya sebatas 
pengajaran saja karena pengajaran hanyalah sebagai transfer of knowledge process. Walaupun dalam proses pendidikan juga berlangsung proses pengajaran, namun pendidikan bisa terjadi tanpa proses pengajaran, tetapi melalui perilaku. Karena itu pendidikan yang ditawarkan kepada orang dewasa ujungujungnya hendaklah dapat mengubah perilaku dan sikap mental mereka. Hasil pendidikan orang dewasa tidak hanya mereka pandai dalam sesuatu ilmu tapi juga bijak dalam memanfaatkan ilmu yang dikuasainya. Sebagai contoh; seseorang petani yang telah diberitahu tentang proses terjadinya kebakaran hutan hendaknya tidak lagi membabat hutan lalu membakarnya atau menerapkan sistim berladang berpindah-pindah. Begitu juga petani yang sudah diajarkan cara menganalisis jenis usaha tani hendaknya tidak lagi merugi dalam berusaha tani, sebaliknya mampu memilih jenis usaha tani yang menguntungkan. Dengan kata lain, mereka tidak hanya bisa jadi pengamat saja setelah keluar dari proses pendidikan yang ditempuhnya, melainkan juga terjadi perubahan prilaku yang menguntungan pada dirinya.

\section{- Belajar Mengingat dan Melupakan}

\section{(Learning to recapture and learning to unlearn)}

Artinya pendidikan pada orang dewasa tersebut hendaklah sesuai dengan kebutuhan dan kondisi nyata. Pola-pola pendidikan yang tumbuh dan hadir bukan karena keterlibatan pemerintah seperti pesantren, perguruan, paguyuban, dan kongsi-kongsi yang sudah melembaga begitu lama dan dilaksanakan oleh masyarakat hendaknya dapat dipelihara. Kita perlu menggalinya kembali karena masyarakat merasakan adanya kebermaknaan dari program-program belajar yang disajikan dalam lembaga pendidikan tersebut. Di sini kita belajar mengingat kembali sistim nilai yang turut membantu pengembangan pendidikan orang dewasa dalam lembaga tersebut. Kebiasaan yang baik perlu terus diingat dan dibiasakan dalam kehidupan sehari-hari. Sering kita melupakan 
strategi dan faktor-faktor yang mengantarkan keberhasilan kita dalam mencapai sesuatu. Karena itu, agar pendidikan yang ditawarkan kepada orang yang telah dewasa dapat terlayani, dicintai, dan dicari masyarakat kita harus berani meniru apa yang baik dari apa yang tumbuh dan berkembang di masyarakat dan dalam diri kita, kemudian diperkaya dengan sentuhansentuhan yang sistematis dengan ilmu pengetahuan dan teknologi yang sesuai dengan lingkungan dimana kita berada.

Di sisi lain, kita harus berani dan belajar pula meninggalkan atau membuang hal-hal yang selama ini digunakan tetapi tidak sesuai lagi dengan tuntutan perkembangan. Kebiasaan atau hal-hal yang sering menjadi penghalang dalam mencapai sesuatu tujuan demi keberhasilan hidup perlu ditinggalkan dan dibuang jauh-jauh. Jadi tugas pemerintah dalam pelayanan pendidikan orang dewasa sebenarnya cukup menumbuhkan situasi yang menguntungkan untuk membangkitkan semangat masyarakat untuk mulai dan terus belajar, sehingga terwujudlah masyarakat yang gemar belajar. Dengan demikian, pendidikan yang bertumpu pada masyarakat perlu terus ditumbuhkembangkan.

\section{F. KESIMPULAN}

Pendidikan non formal adalah salah satu jalur pendidikan yang dianggap sama pentingnya dengan pendidikan formal. Pendidikan non formal ini berbasiskan pendidikan orang dewasa karena sebagian besar peserta didiknya adalah orang dewasa yang datang dengan berbagai latar belakang sosial budaya, minat, serta pengalaman hidup yang berbeda. Karena itu penggunaan metode pembelajaran dalam pendidikan orang dewasa berimplikasi pada penggunaan teknik pembelajaran yang dipandang cocok digunakan di dalam menumbuhkan perilaku warga belajar.

Prinsip andragogi dalam pendidikan orang dewasa merupakan kegiatan belajar yang paling efisien dan paling dapat diterima serta 
merupakan alat yang dinamis dan fleksibel dalam membantu orang dewasa belajar. Oleh karena itu penggunaan metode belajar diperlukan berdasarkan prinsip-prinsip belajar orang dewasa. Metode belajar orang dewasa adalah cara mengorganisir peserta agar mereka melakukan kegiatan belajar, baik dalam bentuk kegiatan teori maupun praktek.

Prinsip belajar yang dapat digunakan dalam kegiatan belajar orang dewasa harus (1) berpusat pada masalah, (2) menuntut dan mendorong peserta untuk aktif, (3) mendorong peserta untuk mengemukakan pengalaman sehari-harinya, (4) menumbuhkan kerja sama, baik antara sesama peserta, dan antara peserta dengan tutor, dan (5) lebih bersifat pemberian pengalaman, bukan merupakan transformasi atau penyerapan materi.

\section{DAFTAR RUJUKAN}

Apps,0Jerold W.01973.0Toward A Working Philosophy of adult Education,OPublications in Continuing Education and Eric Clearinghouse on Adult Education : Syracuse University, Syracuse New York

Asngari,0Pang S,02003,0Pentingnya Memahami Falsafah Penyuluhan Pembangunan dalam Rangka Pemberdayaan Masyaraka, dalam buku Membentuk Pola Perilaku Manusia Pembangunan. Penerbit IPB Press. Bogor

Boyd, Robert. D. A Psychological Defenition of Adult education. Adult Leadership. 1966. University of Wincosin Press.

Dharm Vir. 1993. Psikologi Orang Dewasa dan Metoda Pendidikan. Penerbit Pusat Latihan dan Penataran Perkoperasian. Departemen Koperasi. Jakarta.

Houle, Cyril O. The Inquiring Mind. 1961. Universirty of Wincosin Press. Lindeman, Eduard C. 1961. The Meanin of Adult Education. Penenerbit Harvest House. Montreal.

Roger, Carl. Freedom to Learn. 1969. Columbus OH. Charles E. Merill Publishing Co. 